\title{
Evaluation of Coloanal Anastomosis after Resection Low Rectal Cancer
}

\author{
Ahmed Ali Mohammed ${ }^{1}$ MSc, Ayman Mohammed Abdul-mohaymen ${ }^{2, *}$ MD, Magdy Salah El-Din \\ Hussain $^{2}$ MD
}

\begin{abstract}
*Corresponding Author:
Ahmed Ali Mohammed ahmedali099151@gmail.com

Received for publication December 11, 2019; accepted January28, 2020; published on line February 2, 2020.

Copyright 2020 The Authors published by Al-Azhar University, Faculty of Medicine, Cairo, Egypt. All rights reserved. This an openaccess article distributed under the legal terms, where it is permissible to download and share the work provided it is properly cited. The work cannot be changed in anyway or used commercially.
\end{abstract}

doi: $10.21608 /$ aimj.2020.20870.101 2

1Surgical Oncology

Departement, Damanhour

Oncology Center, Albeheira,

Egypt

2General Surgery

Departement, Al-Azhar

University, Cairo, Egypt

\section{INTRODUCTION}

The primary goal for the surgical treatment of rectal cancer is to achieve an oncologic cure while preserving function. Total mesorectal excision (TME) is the standard surgical procedure for rectal cancer. The concept of TME is the elimination of potential sources of local recurrence by completely excising the mesorectum through sharp pelvic dissection. $^{1,2}$

However, surgical treatment for low rectal cancer remains challenging, particularly with regard to the preservation of the anal sphincter. Anatomically, the mesorectum disappears at a distance of 1-2 cm above the anorectal sling, and only the rectal wall remains to the anal hiatus. Thus, there are greater risks of direct tumor invasion of the adjacent structures and of a positive circumferential resection margin (CRM) in low rectal lesions. ${ }^{3}$

Advances in surgical techniques and multimodal treatment have led to the possibility of sphincter preservation in patient who have traditionally adequate preoperative sphincter function and continence. required abdominoperineal resection (APR) in the past. In this regard, intersphincteric resection (ISR) and colo-anal anastomosis (CAA) has been described by Schiessel. ${ }^{4}$ As the definitive surgical technique for anal sphincter preservation, and now, ISR in combination with preoperative chemo radiation therapy (CRT) is increasingly being performed in patient with low rectal cancers.

\section{PATIENTS AND METHODS}

This study included a total 10 patients who underwent total mesorectal excision and colo anal anastomosis attending at Damanhur Oncology Center. Approval of the ethical committee and a written informed consent from all the subjects were obtained. This study conducted between November 2018 and November 2019, including the follow up time.

\section{Inclusion criteria:}

Tumor's distance $<5 \mathrm{~cm}$ from anal verge down to the dentate line, the tumor restricted to the rectal wall or internal sphincter, Absence of distant metastasis, well / moderate differentiated tumor an

\section{Exclusion criteria:}

Patient unfit for major surgery, Patients unwilling to take part in the study, Emergent operation were 
performed for intestinal obstruction or acute bleeding and recurrent tumor.

\section{Surgical technique}

The gold standard of rectal cancer surgery is total mesorectal excision (TME) which introduced by Heald. ${ }^{5}$ with reconstruction by coloanal anastomosis: Straight tube CAA can be performed using the double stapled technique, or a hand sewn anastomosis can be performed transanally. ${ }^{6}$

\section{Statistical analysis:}

Data were analyzed using Statistical Program for Social Science (SPSS) version 20.0. Quantitative data were expressed as mean \pm standard deviation (SD). Qualitative data were expressed as frequency and percentage. Mean (average): the central value of a discrete set of numbers, specifically the sum of values divided by the number of values. Standard deviation (SD): is the measure of dispersion of a set of values. A low SD indicates that the values tend to be close to the mean of the set, while a high SD indicate that the values are spread out over a wider range.

\section{RESULTS}

We included 10 cases of low rectal cancer. The demographic data of this patients were summarized in table 1.

This table shows the description of demographic data in studied patients. As regard age, the mean age of studied patients was $47.5 \pm 19.2$ years with minimum age of 27 years and maximum age of 67 years (range $27-67$ ). As regard sex, there were 6 males $(60 \%)$ and 4 females $(40 \%)$ in the studied patients. As regard BMI, the mean BMI of studied patients was $25.4 \pm 5.2\left(\mathrm{~kg} / \mathrm{m}^{2}\right)$ with minimum BMI of $21.3\left(\mathrm{~kg} / \mathrm{m}^{2}\right)$ and maximum BMI of $29.6\left(\mathrm{~kg} / \mathrm{m}^{2}\right)$ (range $21.3-29.6$ ).

\begin{tabular}{|l|l|c|c|}
\hline \multicolumn{2}{|c|}{ Variables } & $\begin{array}{c}\text { Studied patients }(\mathrm{N}= \\
10)\end{array}$ \\
\hline Age (years) & $\begin{array}{l}\text { Mean } \\
\pm \text { SD }\end{array}$ & \multicolumn{2}{|c|}{$47.5 \pm 19.2$} \\
\cline { 2 - 4 } & $\begin{array}{l}\text { Min - } \\
\text { Max }\end{array}$ & \multicolumn{2}{|c|}{$27-67$} \\
\hline Sex (n, \%) & Male & 6 & $60 \%$ \\
\cline { 2 - 4 } & Female & 4 & $40 \%$ \\
\hline BMI (kg/m²) & $\begin{array}{l}\text { Mean } \\
\pm \text { SD }\end{array}$ & $25.4 \pm 5.2$ \\
\cline { 2 - 4 } & $\begin{array}{l}\text { Min - } \\
\text { Max }\end{array}$ & $21.3-29.6$ \\
\hline
\end{tabular}

Table 1: Demographic data of the studied patients among the included patients of this study the early post-operative complication were summarized in table 2

\begin{tabular}{|c|c|c|c|}
\hline \multicolumn{2}{|c|}{ Variables } & \multicolumn{2}{c|}{$\begin{array}{c}\text { Studied patients } \\
(\mathrm{N}=10)\end{array}$} \\
\hline \multirow{3}{*}{$\begin{array}{c}\text { Local } \\
\text { complications }\end{array}$} & Hemorrhage & 0 & $0 \%$ \\
\cline { 2 - 4 } & Leakage & 2 & $20 \%$ \\
\cline { 2 - 4 } & $\begin{array}{c}\text { Wound } \\
\text { infection }\end{array}$ & 3 & $30 \%$ \\
\cline { 2 - 4 } & $\begin{array}{c}\text { Burst } \\
\text { abdomen }\end{array}$ & 1 & $10 \%$ \\
\cline { 2 - 4 } & Ileus & 3 & $30 \%$ \\
\hline \multirow{7}{*}{$\begin{array}{c}\text { General } \\
\text { complications }\end{array}$} & MI & 1 & $10 \%$ \\
\cline { 2 - 4 } & Pneumonia & 2 & $20 \%$ \\
\cline { 2 - 4 } & DVT & 1 & $10 \%$ \\
\cline { 2 - 4 } & UTI & 2 & $20 \%$ \\
\hline
\end{tabular}

Table 2:Post-operative complication among studied patients; this table shows the description of early post-operative complications in studied patients.

As regard local complications, leakage occurred in 2 patients (20\%), wound infection occurred in 3 patients (30\%), Burst abdomen occurred in 1 patient $(10 \%)$, Ileus occurred in 3 patients $(30 \%)$ while hemorrhage had not occurred in our patients.

As regard general complications, $\mathrm{MI}$ occurred in 1 patient $(10 \%)$, pneumonia occurred in 2 patients (20\%), DVT occurred in 1 patient (10\%) and UTI occurred in 2 patients $(20 \%)$.

\begin{tabular}{|c|c|c|c|}
\hline \multicolumn{2}{|c|}{ Variables } & \multicolumn{2}{c|}{$\begin{array}{c}\text { Studied patients } \\
(\mathrm{N}=10)\end{array}$} \\
\hline \multirow{2}{*}{$\begin{array}{c}\text { Late } \\
\text { complications }\end{array}$} & Recurrence & 0 & $0 \%$ \\
\cline { 2 - 4 } & Stenosis & 2 & $20 \%$ \\
\cline { 2 - 4 } & Fistula & 2 & $20 \%$ \\
\hline
\end{tabular}

Table 3: Late postoperative complications among studied patients

This table shows the description of late postoperative complications in studied patients. Stenosis occurred in 2 patients (20\%), Fistula occurred in 2 patients $(20 \%)$, while recurrence had not occurred in any patient.

\begin{tabular}{|c|c|c|c|}
\hline \multicolumn{2}{|c|}{ Variables } & \multicolumn{2}{c|}{$\begin{array}{c}\text { Studied } \\
\text { patients (N = } \\
10)\end{array}$} \\
\hline Histopathology & $\begin{array}{c}\text { Well } \\
\text { differentiated } \\
\text { AC }\end{array}$ & 3 & $30 \%$ \\
& $\begin{array}{c}\text { Moderately } \\
\text { differentiated } \\
\text { DC }\end{array}$ & 7 & $70 \%$ \\
\hline TNM staging & T1 N0 M0 & 1 & $10 \%$ \\
\cline { 2 - 4 } & T3 N0 M0 & 3 & $30 \%$ \\
\cline { 2 - 4 } & T3 N1 M0 & 2 & $20 \%$ \\
\cline { 2 - 4 } & T3 N2 M0 & 4 & $40 \%$ \\
\hline
\end{tabular}

Table 4: TNM staging and histopathology in studied patients

This table shows the description of histopathology and TNM staging in studied patients. As regard histopathology, 3 patients (3\%) showed well 
differentiated adenocarcinoma and 7 patients (70\%) showed moderately differentiated adenocarcinoma. As regard TNM staging, 1 patient $(1 \%)$ was T1N0M0, 3 patients $(30 \%)$ were T3NOM0, 2 patients $(20 \%)$ were $\mathrm{T} 3 \mathrm{~N} 1 \mathrm{M} 0$ and 4 patients $(40 \%)$ were $\mathrm{T} 3 \mathrm{~N} 2 \mathrm{M} 0$.

\section{CONCLUSION}

The ISR and CAA technique provides an opportunity to perform sphincter saving surgery in treatment of distal rectal cancer. This technique performs with acceptable functional outcomes. Moreover, if the adequate distal margin is provided, the local recurrence and survival rates after CAA may even be better than those of APR. The CAA technique should be considered as a safe procedure and a valuable alternative to APR in selected patients with distal rectal cancer. Further research is needed to fully clarify the effects of different modifications (preoperative CRT, ISR-subtype, type of coloanal anastomosis) to the ISR procedure on oncological and functional outcome and quality of life.

\section{REFERENCES}

1. Heald J, Husband $M$ and Ryall $H$. The mesorectum in rectal cancer surgery - the clue to pelvic recurrence. $\mathrm{Br} \quad J$ Surg; 1982 69(10):613-6.

2. Wibe A, Rendedal R, Svensson E, et al. Prognostic significance of the circumferential resection margin following total mesorectum excision for rectal cancer. Br J Surg;2002 89:32734

3. Kim W, Kim K, Min S, et al. Factors associated with anastomotic recurrence after total mesorectal excision in rectal cancer patients. $J$ Surg Oncol; 2009 99(1):58-64.

4. Schiessel R, Karner-Hanusch J, Herbst F, et al. Intersphincteric resection for low rectal tumours. Br J Surg; 1994 81(9):1376-8.

5. Heald RJ. The "Holy Plane" of rectal surgery. $J$ Roy Soc Med; 1988 81: 503-508.

6. Van Helmond J and Beart W. Cancer of the rectum: Operative management and adjuvant therapy. Current Therapy in Colon and Rectal Surgery. 2nd ed. Philadelphia, Pa: Mosby;2005
7. Kapiteijn E, Marijnen A, Nagtegaal D, et al. Dutch Colorectal Cancer Group: Preoperative radiotherapy combined with total mesorectal excisi on for resectable rectal cancer. $N$ Engl $J$ Med; 2001 345:638-46.

8. Franke J, Parekh H, Starr S, et al. Total Neoadjuvant Therapy: A Shifiting Paradigm in Locally Advanced Rectal Cancer Management.2018

DOI: $10.1016 /$ j.clcc. 2017.06 .008

9. Tilney $\mathrm{S}$ and Tekkis P. extending the horizons of restorative rectal surgery: intersphincteric resection for low rectal cancer. Colorectal Disease; 2008 10(1):3-15.

10. Cong C, Chen S, Ma X, et al. Laparoscopic intersphincteric resection for low rectal cancer: comparison of stapled and manual coloanal anastomosis. Colorectal Disease; 2014 16(5):353-8.

11. Neutzling B, Lustosa A, Proenca M, et al. Stapled versus handsewn methods for colorectal anastomosis surgery. The Cochrane Database of Systematic Reviews; 2012: Cd003144.

12. Harms A and Heise P. Pharmacologic Management of postoperative Ileus; The Next Chapter in Surgery. Ann Surg; 2007 245:364-5.

13. Matthiessen P, Hansson L, Sjodahl R, et al. Anastomotic-vaginal fistula (AVF) after anterior resection of the rectum for cancer-occurrence and risk factors. Colorectal Dis; 2010 12(4):351-357.

14. Rullier E, Laurent C, Bretagnol F, et al. Sphincter-saving resection for all rectal carcinomas: the end of the 2-cm distal rule. Ann Surg; 2005 241:465-469.

15. Yamada K, Ogata S, Saiki Y, et al. Functional results of intersphincteric resection for low rectal cancer. Br J Surg; 2007 94:1272-7. 